\title{
Content of Heavy Metals in Soil and in Pineapple Fertilized With Sewage Sludge
}

\author{
Geraldo R. Zuba Junio ${ }^{1}$, Regynaldo A. Sampaio ${ }^{1}$, Luiz A. Fernandes ${ }^{1}$, Rodinei F. Pegoraro ${ }^{1}$, Victor M. Maia ${ }^{2}$, \\ Paulo H. S. Cardoso ${ }^{3}$, Izabelle de P. Sousa ${ }^{4} \&$ Iago T. R. Vieira ${ }^{1}$ \\ ${ }^{1}$ Instituto de Ciências Agrárias, Universidade Federal de Minas Gerais. Montes Claros, MG, Brazil \\ ${ }^{2}$ Universidade Estadual de Montes Claros, Janaúba, MG, Brazil \\ ${ }^{3}$ Universidade de São Paulo, Piracicaba, SP, Brazil \\ ${ }^{4}$ Universidade Federal de Viçosa, Viçosa, MG, Brazil \\ Correspondence: Geraldo Ribeiro Zuba Junio, Instituto de Ciências Agrárias, Universidade Federal de Minas \\ Gerais. Montes Claros, MG, Brazil. E-mail: juniozuba@yahoo.com.br
}

Received: February 8, $2019 \quad$ Accepted: April 21, $2019 \quad$ Online Published: June 30, 2019

doi:10.5539/jas.v11n9p281 URL: https://doi.org/10.5539/jas.v11n9p281

\begin{abstract}
The usage of sewage sludge in agriculture can increase the levels of heavy metals in the soil, compromising their use as fertilizer. The objective of this study was to evaluate the contamination of soil and pineapple by heavy metals after the application of treated sewage sludge by different forms in three orders of soils under greenhouse conditions. The treatments, in a factorial scheme $7 \times 3$ were distributed in a randomized complete block design with three replications, corresponding to seven fertilization management: soil without fertilization, chemical fertilization, fertilization with composted sludge sewage, fertilization with vermicompost sewage sludge, fertilization with solarized sewage sludge, fertilization as sewage sludge dried in a Bruthus-Albrecht rotary sludge dryer and fertilization with limed sludge sewage, combined with three orders of soils: Cambisol, Nitisol and Acrisol. The $\mathrm{Zn}, \mathrm{Cu}, \mathrm{Cr}, \mathrm{Pb}, \mathrm{Ba}, \mathrm{Cd}, \mathrm{Ni}$, As and $\mathrm{Se}$ contents were analyzed in the soil, in the leaf of greater length (D leaf) and in the fruit pulp of the pineapple. The Acrisol provided more favorable conditions to the increase in the availability and absorption of $\mathrm{Pb}$ and $\mathrm{As}$ by $\mathrm{D}$ leaf and fruit of the pineapple. Fertilization with composted, vermicompost and solarized sewage sludge provided high levels of $\mathrm{Pb}, \mathrm{As}, \mathrm{Zn}$ in leaf $\mathrm{D}$ and in the pineapple fruit, relating the interference of sludge stabilization process with the absorption of metals by pineapple fruits.
\end{abstract}

Keywords: Ananas comosus var. comosus, biosolid, organic fertilization, solid waste

\section{Introduction}

The agricultural usage of sewage sludge or products from its stabilization is an important alternative for the reduction in production costs and to the increase of the productivity of several crops, since this residue promotes physical and chemical improvements of the soil due to its high levels of nutrients and organic matter (Nascimento et al., 2004; Lemainski \& Silva, 2006; Zuba Junio et al., 2012; Ribeirinho et al., 2012).

Nitrogen is the most important plant nutrient in the sewage sludge. It is the element that determines the dose of sludge to be applied in crop fertilization when there is no surplus of heavy metals (Brasil, 2006). However, the application of sewage sludge based only on the nitrogen concentration can cause nutritional imbalance, since the concentration of potassium in this residue is very low, which may limit the production of the plants. On the other hand, in tropical conditions, the application of sewage sludge based on potassium concentration alone can raise nitrogen levels in the soil to very high levels, increasing the risk of contamination of the water table with this element. So, the application of sewage sludge based on nitrogen concentration, however, complemented with phosphorus and potassium, seems to be the best management for this fertilizer use (Tontti et al., 2017). In this context, the pineapple presents a high demand for N (Caetano et al., 2013; Cardoso et al., 2013) and sludge can replace it, which is an important fertilizer economy for the crop besides providing an adequate destination of the organic residue (Mota et al., 2018).

On the other hand, the sludge may contain higher levels of heavy metals than the soil, particularly $\mathrm{Pb}, \mathrm{Ni}, \mathrm{Cd}, \mathrm{Cr}$, $\mathrm{Cu}$, and $\mathrm{Zn}$, indicating its usage as fertilizer in agriculture (Nogueira et al., 2007; Oliveira et al., 2009; 
Nascimento et al., 2014a; Mota et al., 2018). Several studies point to the dependence on soil contamination with heavy metals, the way sewage sludge is managed in agriculture and soil composition. In the long term, with successive applications of this residue, it was observed the rise in the contents of some heavy metals in the soil (Nascimento et al., 2004; Gomes et al., 2006; Silva et al., 2006).

The safe use of sludge in agriculture depends on the adoption of stabilization processes, as they reduce the presence of biological contaminants and can reduce the solubility of heavy metals. Among those processes, the stabilization of sludge by solarization, composted, vermicompost and liming stand out (Nascimento et al., 2014a). According to Nogueira et al. (2007), due to the $\mathrm{pH}$ increase, the use of limed sewage sludge promoted an intense reduction in the availability of heavy metals in the soil. In this study, the application of limed sewage sludge provided a soil $\mathrm{pH}$ value of 6.63 , while the application of solarized sewage sludge with the same amount of nitrogen raised soil $\mathrm{pH}$ to 8.33 . At this $\mathrm{pH}$ increase the reductions in available element contents were $28 \% \mathrm{Zn}$, $49 \% \mathrm{Cu}, 80 \% \mathrm{~Pb}$ and $41 \% \mathrm{Ni}$.

The objective of this work was to evaluate the contamination of pineapple with heavy metals in three orders of soils after the application of sewage sludge submitted to different stabilization processes.

\section{Material and Methods}

The experiment was carried out in a screened type greenhouse in the Montes Claros county, Minas Gerais state, Brazil, at latitude $16^{\circ} 51^{\prime} 38^{\prime \prime} \mathrm{S}$ and longitude $44^{\circ} 55^{\prime} 00^{\prime \prime} \mathrm{W}$, from November 2014 to September 2016, by cultivating pineapple variety Pérola, in three types of soil, whose chemical and physical attributes of the $0-20 \mathrm{~cm}$ deep layers are presented in Table 1. The climatic conditions in the growing period are shown in Figure 1.

Table 1. Chemical and physical attributes of Cambisol (CM), Nitisol (NT) and Acrisol (AC) used in the study

\begin{tabular}{|c|c|c|c|c|c|c|c|c|c|c|c|c|c|c|}
\hline Soil $^{1}$ & $\mathrm{H}_{\left(\mathrm{H}_{2} \mathrm{O}\right)}$ & P-rem & $\mathrm{N}$ & $\mathrm{P}$ & K & $\mathrm{Ca}$ & $\mathrm{Mg}$ & $\mathrm{Al}$ & $\mathrm{H}+\mathrm{Al}$ & SB & $\mathrm{t}$ & $\mathrm{T}$ & $\mathrm{m}$ & V \\
\hline & & $\mathrm{mg} \mathrm{L}^{-1}$ & $\mathrm{~g} \mathrm{dm}^{-3}$ & \multicolumn{2}{|c|}{$---\mathrm{mg} \mathrm{dm}^{-3}---$} & \multicolumn{7}{|c|}{ - } & \multicolumn{2}{|c|}{---- \% ---- } \\
\hline $\mathrm{CM}$ & 6.8 & 39.00 & 6.02 & 4.99 & 396.50 & 5.60 & 1.55 & 0.0 & 1.35 & 8.78 & 8.78 & 9.52 & 0.00 & 86 \\
\hline NT & 5.8 & 39.80 & 6.46 & 3.05 & 324.00 & 4.65 & 1.15 & 0.0 & 2.09 & 6.63 & 6.63 & 8.72 & 0.00 & 76 \\
\hline $\mathrm{AC}$ & 4 & 43.32 & 6.04 & 6.08 & 154.00 & 8.30 & 2.25 & 0.0 & 1.87 & 10.94 & 10.94 & 12.81 & 0.00 & 86 \\
\hline Soil & OM & $\mathrm{CO}$ & $\mathrm{Cr}$ & $\mathrm{Cu}$ & $\mathrm{Zn}$ & $\mathrm{Pb}$ & $\mathrm{Ba}$ & $\mathrm{Se}$ & As & Sand & \multicolumn{2}{|c|}{ Silt } & \multicolumn{2}{|l|}{ Clay } \\
\hline & \multicolumn{2}{|c|}{---- dag $\mathrm{kg}^{-1}$---- } & & & ------ & $\mathrm{dm}^{-3}-$ & & 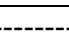 & 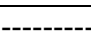 & \multicolumn{5}{|c|}{--------- dag kg ${ }^{-1}$--- } \\
\hline $\mathrm{CM}$ & 4.06 & 2.36 & 45.77 & & 33.77 & 21.40 & 9.89 & $<0.1$ & 3.52 & 25.03 & \multicolumn{2}{|c|}{37.63} & \multicolumn{2}{|l|}{37.34} \\
\hline NT & .19 & 3.81 & 31.93 & 7.64 & 15.88 & 14.55 & 1.46 & $<0.1$ & 4.93 & 30.35 & \multicolumn{2}{|c|}{27.13} & \multicolumn{2}{|l|}{42.52} \\
\hline $\mathrm{AC}$ & 6.56 & 3.81 & 24.83 & 10.47 & 21.87 & 13.20 & 2.94 & $<0.1$ & 3.77 & 36.42 & \multicolumn{2}{|c|}{24.23} & \multicolumn{2}{|l|}{39.35} \\
\hline
\end{tabular}

Note. ${ }^{1}$ Chemical and physical attributes determined according to Embrapa methodologies (Embrapa, 1997), except for the total concentrations of $\mathrm{Cr}, \mathrm{Cu}, \mathrm{Zn}, \mathrm{Pb}, \mathrm{Ba}$, Se and As, which were determined according to the methodology of McGrath and Cunliffe (1985).
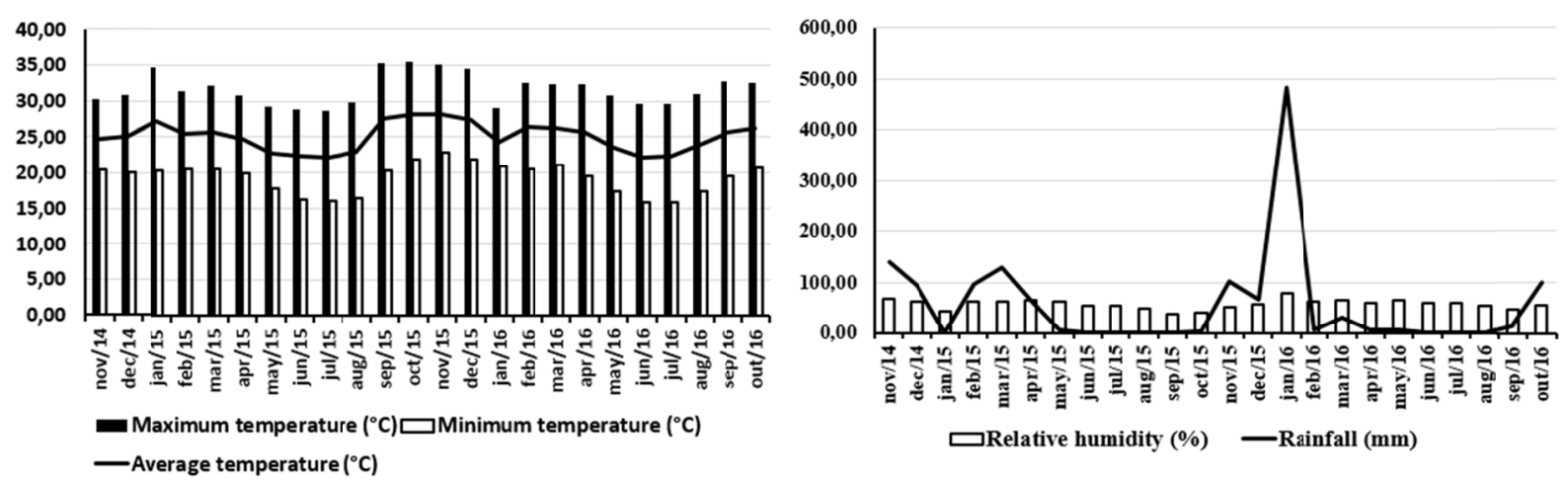

Figure 1. Monthly average values of maximum temperature, minimum temperature, average temperature, relative humidity and precipitation during the period of cultivation of pineapple

The experiment was conducted in a randomized block design with three replicates. The treatments were distributed in a $7 \times 3$ factorial scheme, as it follows: soil without fertilization, chemical fertilization (NPK), fertilization with composted sewage sludge, fertilization with vermicomposting sewage sludge, fertilization with sewage sludge, 
fertilization with sewage sludge dried in dryers and fertilizers with sewage sludge combined with three orders of soils: Cambisol (CM), Nitisol (NT) and Acrisol (AC).

The fertilization corresponding to the NPK treatment was based on the crop requirement and on the chemical analysis of the three orders of soils (Souza et al., 1999), using $20.0 \mathrm{~g}$ of urea per plant, $16.7 \mathrm{~g}$ of simple superphosphate per plant and $8.6 \mathrm{~g}$ of $\mathrm{KCl}$ per plant in the Cambisol and the Nitisol, whereas in Acrisol, $20.0 \mathrm{~g}$ of urea per plant, $16.7 \mathrm{~g}$ of simple superphosphate per plant and $17.2 \mathrm{~g} \mathrm{KCl}$ per plant, respectively.

The sewage sludge was collected at the Estação de Tratamento de Esgoto-ETE (Sewage Treatment Plant) of Montes Claros-MG, operated by COPASA-MG. The treatment line is composed of preliminary treatment and UASB anaerobic reactor, in which the generated sludge is centrifuged and dried in an oven at $350{ }^{\circ} \mathrm{C}$ for 30 minutes and classified as a type A sludge, according to CONAMA Resolution no. 375 (Brasil, 2006). Type A sewage sludge is one containing thermotolerant coliforms with concentration less than $10^{3}$ most probable number (MPN) per gram of total solids (TS), viable helminth eggs with less than 0.25 egg per gram of TS, absence of salmonella in 10 grams of TS and viruses with less than 0.25 plaque forming unit (PFU) per gram of TS.

The limed sewage sludge was obtained by the addition of quicklime in an amount corresponding to $50 \%$ of the dry mass of sewage sludge. The residue dose was based on the soil $\mathrm{pH}$ increase test described in Brasil (2006), in which the amount applied was that in which the final $\mathrm{pH}$ of the soil-limed sludge mixture did not exceed the limit of 7.0, which was: $31.28 \mathrm{~g}$ per plant for the Cambisol; $39.85 \mathrm{~g}$ per plant for Nitisol and $63.79 \mathrm{~g}$ per plant for Acrisol.

For the composting, centrifuged sewage sludge was mixed with grass pruning, whose predominant species was Paspalum notatum (grass-batatais), in order to obtain a C:N ratio of 30:1. Periodically, temperature and humidity were monitored, and systematic turning of the piles was performed for material homogenization and humidity control and aeration.

To obtain the vermicompost, a pre-composed of sewage sludge mixed with grass pruning as described for composting. After one month of composting, it was used as a substrate for vermicomposting with California red worms (Eisenia foetida).

For the treatments with sewage sludge, except for the limed sewage sludge, the amounts applied were based on the nitrogen content available in the residues for subsurface application (Brasil, 2006) and on the requirement of this element by pineapple (Souza et al., 1999), which was $2.43 \mathrm{~kg}$ per plant of composted sewage sludge, $2.37 \mathrm{~kg}$ per plant of vermicompost sewage sludge, $1.58 \mathrm{~kg}$ per plant of solarized sludge plant and $1.33 \mathrm{~kg}$ per plant of sludge dried in a dryer.

The chemical characteristics of the fertilizers used in the study and the contribution of heavy metals are presented in Tables 2 and 3.

Table 2. Characteristics ${ }^{1}$ of the chemical fertilizers and types of sewage sludge used in the study ${ }^{1}$

\begin{tabular}{|c|c|c|c|c|c|c|}
\hline Treatments & $\mathrm{N}$ (available) & $\mathrm{Zn}$ & $\mathrm{Cu}$ & $\mathrm{Cr}$ & $\mathrm{Pb}$ & As \\
\hline & $\mathrm{g} \mathrm{kg}^{-1}$ & --------- & ------ & -- mg kg & -------- & 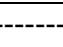 \\
\hline $\mathrm{CS}$ & 12.70 & 452.82 & 8.40 & 88.68 & 49.07 & 0.67 \\
\hline VS & 22.64 & 381.31 & 7.06 & 35.41 & 32.04 & 0.33 \\
\hline SS & 20.12 & 718.27 & 24.29 & 31.35 & 48.08 & 0.31 \\
\hline $\mathrm{SD}$ & 12.56 & 778.85 & 26.10 & 32.83 & 51.08 & 0.27 \\
\hline LS & 11.44 & 375.05 & 5.25 & 18.91 & 44.48 & 0.45 \\
\hline $\mathrm{MCA}$ & - & 2,800 & 1,500 & 1,000 & 300 & 41 \\
\hline Urea & 440.00 & 2.50 & 16.20 & 0.00 & 8.00 & 0.00 \\
\hline SSP & 0.00 & 142.00 & 16.20 & 333.00 & 116.0 & 0.00 \\
\hline $\mathrm{KCl}$ & 0.00 & 2.50 & 4.62 & 0.00 & 83.83 & 0.00 \\
\hline
\end{tabular}

Note. ${ }^{1}$ The content of $\mathrm{N}$ available in the sewage sludge was estimated according to the calculation presented in Brazil (2006), which is based on the total and inorganic N contents determined by the Kjeldahl Method (Tedesco et al., 1995); The levels of $\mathrm{N}$ and heavy metals in the fertilizers were determined according to the methodologies of Alcarde (2009); The levels of heavy metals in the sewage sludge were determined according to Malavolta's methodologies (2006); The elements $\mathrm{Ba}, \mathrm{Cd}, \mathrm{Ni}$, and Se were neither detected nor quantified; CS-Composted sewage sludge; VS-Vermicompost sewage sludge; SS-Solarized sewage sludge; SD-Sewage sludge dried in dryer; LS-Lime sewage sludge; MCA-Maximum concentration allowed in sewage sludge or its by-product (Brasil, 2006); SSP-Single superphosphate. 
Table 3. Input of heavy metal ${ }^{1}$ from chemical fertilizer and types of sewage sludge applied in the study

\begin{tabular}{|c|c|c|c|c|c|}
\hline Treatment & $\mathrm{Zn}$ & $\mathrm{Cu}$ & $\mathrm{Cr}$ & $\mathrm{Pb}$ & As \\
\hline & --------- & ------ & $-\mathrm{mg} / \mathrm{pla}$ & -------- & $-\cdots$ \\
\hline CS $(2.43 \mathrm{~kg} / \mathrm{plant})$ & $1,100.35$ & 20.41 & 215.49 & 119.24 & 1.63 \\
\hline VS $(2.37 \mathrm{~kg} /$ plant $)$ & 903.71 & 16.73 & 83.92 & 75.94 & 0.78 \\
\hline $\mathrm{SS}(1.58 \mathrm{~kg} / \mathrm{plant})$ & $1,134.87$ & 38.38 & 49.53 & 75.97 & 0.49 \\
\hline $\mathrm{SD}(1.33 \mathrm{~kg} / \mathrm{plant})$ & $1,035.87$ & 34.71 & 43.66 & 67.94 & 0.36 \\
\hline LS-CM (31.28 g/plant) & 11.73 & 0.16 & 0.59 & 1.39 & 0.01 \\
\hline LS-NT (39.85 g/plant) & 14.95 & 0.21 & 0.75 & 1.77 & 0.02 \\
\hline LS-AC (63.79 g/plant) & 23.92 & 0.34 & 1.21 & 2.84 & 0.03 \\
\hline \multicolumn{6}{|l|}{$\mathrm{CM}$ and $\mathrm{NT}$ : } \\
\hline Urea (20.0 g/plant) & 0.05 & 0.05 & 0.32 & 0.00 & 0.16 \\
\hline SSP (16.7 g/plant) & 2.37 & 2.37 & 0.27 & 5.56 & 1.94 \\
\hline $\mathrm{KCl}(8.6 \mathrm{~g} /$ plant $)$ & 0.02 & 0.02 & 0.04 & 0.00 & 0.72 \\
\hline \multicolumn{6}{|l|}{$\mathrm{AC}:$} \\
\hline Urea (20.0 g/plant) & 0.05 & 0.05 & 0.32 & 0.00 & 0.16 \\
\hline SSP (16.7 g/plant) & 2.37 & 2.37 & 0.27 & 5.56 & 1.94 \\
\hline $\mathrm{KCl}(17.2 \mathrm{~g} / \mathrm{plant})$ & 0.04 & 0.08 & 0.00 & 1.44 & 0.00 \\
\hline
\end{tabular}

Note. ${ }^{1}$ The levels of heavy metals in the fertilizers were determined according to the methodologies of Alcarde (2009); The levels of heavy metals in the sewage sludge were determined according to Malavolta's methodologies (2006); CS-composted sewage sludge; VS-Vermicompost sewage sludge; SS-Solarized sewage sludge; SD-Sewage sludge dried in dryer; LS-Lime sewage sludge; CM-Cambisol; NT-Nitisol; AC-Acrisol; SSP-Simple superphosphate.

The soils used in the experiment were collected at a depth of 0-20 cm, air dried and passed through a 4-mm sieve, mixed to the different treatments and stored in $10 \mathrm{dm}^{3}$ pots which were filled up to a volume equivalent to $8 \mathrm{dm}^{3}$ where it was planted seedlings of the Pérola cultivar, previously selected by size, approximately $15 \mathrm{~cm}$ long and chemically treated with a systemic insecticide of the neonicotinoid chemical group (Evidence 700WG).

Irrigation was carried out in order to keep soil moisture close to field capacity. The control of weeds, phytopathogens, and insects was carried out constantly after planting the seedlings in the pots, when necessary. Floral induction was also done at 12 months after planting the seedlings by applying $1 \%$ ethereal solution, applied at the center of the leaf rosette, using about $50 \mathrm{~mL}$ of the solution per plant (Oliveira et al., 2002).

At the beginning of the flowering of the plants, which varied from 10 to 13 months after the planting of the seedlings, D leaf of pineapple and soil samples were collected to determine the heavy metal contents. D leaf is the youngest among the adult leaves and the longest of the leaves, with convergent edges at the base (Figure 2). It is the metabolically active leaf of the pineapple, being used in the analysis of the nutritional state of the plant and to evaluate the moment of the floral induction. The $\mathrm{D}$ leaf was cut into $1 \mathrm{~cm}$ wide pieces, eliminating the basal portion without chlorophyll, being homogenized and analyzed (Cunha et al., 1999; Silva, 1999). After the fruit harvest, samples were taken from the pulp to determine the heavy metal contents.


Figure 2. Position of pineapple leaves according to age. A-Older plant leaf, F-Younger plant leaf. Fonte: Catunda et al. (2006) 
The content of $\mathrm{N}$ available in the sewage sludge was estimated according to the calculation presented in Brasil (2006), which is based on the total and inorganic N contents determined by the Kjeldahl Method (Tedesco et al., 1995). On the other hand, the determination of total $\mathrm{N}$ in chemical fertilizers followed the níquel Raney methodology, as described in Alcarde (2009).

The extractions of the Se, As, Ni, $\mathrm{Cd}, \mathrm{Cu}, \mathrm{Zn}, \mathrm{Pb}, \mathrm{Ba}$ e $\mathrm{Cr}$ in the soil were done with aqua regia ( $\mathrm{HCl}: \mathrm{HNO}_{3}, 3: 1$, with $37 \% \mathrm{HCl}$ and $65 \% \mathrm{HNO}_{3}$ ), according to the methodology described in McGrath and Cunliffe (1985), in the sewage sludge and plant tissues were done by nitric-perchloric digestion $\left(65 \% \mathrm{HNO}_{3}+72 \% \mathrm{HClO}_{4}\right)$, according to the methodology described in Malavolta (2006), while the extractions of heavy metals in mineral fertilizers were done with $37 \%$ concentrated $\mathrm{HCl}$ and heated to near dryness and diluted with $2 \mathrm{M} \mathrm{HCl}$ according to Alcarde (2009).

Readings of the soil heavy metals were performed using a Varian atomic absorption spectrophotometer, model AA 240 , with the following quantification limits: Se $\left(4.25 \mu \mathrm{g} \mathrm{dm}^{-3}\right)$, As $\left(2 \mu \mathrm{g} \mathrm{dm}^{-3}\right)$, Ni $\left(5 \mathrm{mg} \mathrm{dm}{ }^{-3}\right)$, Cd $(0.3 \mathrm{mg}$ $\left.\mathrm{dm}^{-3}\right), \mathrm{Cu}\left(0.1 \mathrm{mg} \mathrm{dm}^{-3}\right), \mathrm{Zn}\left(0.15 \mathrm{mg} \mathrm{dm}^{-3}\right), \mathrm{Pb}\left(2.5 \mathrm{mg} \mathrm{dm}^{-3}\right), \mathrm{Ba}\left(5 \mathrm{mg} \mathrm{dm}^{-3}\right)$ and $\mathrm{Cr}\left(1.25 \mathrm{mg} \mathrm{dm}^{-3}\right)$. On the other hand, the metal readings for ' $\mathrm{D}$ ' leaf and fruit pulp were made by mass spectrometer with inductively coupled plasma source (ICP-MS), with the following quantification limits: $\mathrm{As}, \mathrm{Ba}, \mathrm{Pb}\left(1 \mu \mathrm{g} \mathrm{L}{ }^{-1}\right), \mathrm{Cr}, \mathrm{Cu}(0.5 \mu \mathrm{g}$ $\left.\mathrm{L}^{-1}\right)$ and $\mathrm{Se}, \mathrm{Zn}\left(2.5 \mu \mathrm{g} \mathrm{L}^{-1}\right)$.

The data were submitted to analysis of variance and the means of the treatments were compared at $5 \%$ probability by the Scott-Knott test.

\section{Results and Discussion}

Concentrations of $\mathrm{Ba}, \mathrm{Cd}, \mathrm{Ni}$ and $\mathrm{Se}$ in the sewage sludge were below the levels of detection or quantification by the analytical methods used. On the other hand, $\mathrm{Zn}, \mathrm{Cu}, \mathrm{Cr}, \mathrm{Pb}$ and $\mathrm{As}$ were quantified (Table 2), however, they were below the maximum concentrations allowed in sewage sludge or sludge products established by CONAMA Resolution no. 375 (Brasil, 2006).

Regarding contents of As in the soil, there was no interaction between the types of fertilizers and soil orders, whereas, for contents of $\mathrm{Pb}, \mathrm{Cr}, \mathrm{Cu}$, and $\mathrm{Zn}$, there was an interaction between the evaluated factors (Table 4). The Acrisol was the order of soil with the smallest contents of $\mathrm{Pb}, \mathrm{Cr}$ and $\mathrm{As}$, which are considered to be those with the greatest impact on the environment, among the elements considered in this study. In relation to $\mathrm{Pb}$ and $\mathrm{Cr}$, the total contents found after 10 months of cultivation, including that of the control, were greater than the levels obtained in the soil characterization (Table 1), pointing to some additional contribution of these elements by the irrigation water. However, in the case of As, a substantial decrease of this element was observed after the mentioned cultivation period. The levels of $\mathrm{Pb}, \mathrm{Cr}$ and $\mathrm{As}$ in the different soils presented variation close to those observed in the characterization (Table 1). As for $\mathrm{Cu}$ and $\mathrm{Zn}$, the contents were, in general, very close among the orders of soils, with a few variations, possibly related to the absorption of the elements by the plant.

As described in Embrapa (2018), the three orders of soils used in this study are mineral and non-hydromorphic, with high redox potential. The Cambisol presents a little advanced pedogenesis, with the highest silt content in its granulometric composition, and the predominant presence of ilite and kaolinite in its clay fraction, the $\mathrm{pH}$ of this soil being close to neutrality (Table 1). On the other hand, Nitisol has advanced pedogenic evolution by the performance of ferralitization with intense hydrolysis, causing kaolinite-oxidic or even kaolinite composition, or with hydroxyl Al between layers in its clay fraction. It always presents a clayey or very clayey texture and is, in general, moderately acidic to acidic. The Acrisol also presents advanced pedogenetic evolution, however, with incomplete performance of the ferralitization process, with predominance of kaolinite in its clay fraction. In this soil, the upper horizon tends to be more sandy and the acidity varies from strong to moderate. Apparently, the higher organic matter content observed in Acrisol (Table 1) may have caused a greater reduction of the redox potential (Asghar and Kanehiro, 1988), with consequent reduction of iron oxides and increased availability of the mentioned metals. 
Table 4. Contents of heavy metals in the soil fertilized with chemical fertilizer and types of sewage sludge

\begin{tabular}{|c|c|c|c|c|c|c|c|c|c|c|c|}
\hline \multirow{2}{*}{ Element $\left(\mathrm{mg} \mathrm{dm}^{-3}\right)$} & \multirow{2}{*}{ Soil } & \multicolumn{7}{|c|}{ Fertilizations } & \multirow{2}{*}{ Aver } & \multirow{2}{*}{ CV (\%) } & \multirow{2}{*}{$\mathrm{MC}$} \\
\hline & & $\mathrm{T} 1$ & $\mathrm{~T} 2$ & $\mathrm{~T} 3$ & $\mathrm{~T} 4$ & T5 & T6 & $\mathrm{T} 7$ & & & \\
\hline \multirow{3}{*}{$\mathrm{Pb}$} & $\mathrm{CM}$ & $31.73 \mathrm{Aa}$ & $32.94 \mathrm{Aa}$ & $36.13 \mathrm{Aa}$ & $35.03 \mathrm{Aa}$ & $33.68 \mathrm{Aa}$ & $34.90 \mathrm{Aa}$ & $31.50 \mathrm{Aa}$ & - & \multirow{3}{*}{7.51} & \multirow{3}{*}{180} \\
\hline & NT & $33.11 \mathrm{Aa}$ & $30.77 \mathrm{Ab}$ & $37.47 \mathrm{Aa}$ & $31.42 \mathrm{Ab}$ & $35.71 \mathrm{Aa}$ & $34.41 \mathrm{Aa}$ & $26.90 \mathrm{Bc}$ & - & & \\
\hline & $\mathrm{AC}$ & $21.60 \mathrm{Bb}$ & $22.48 \mathrm{Bb}$ & $24.15 \mathrm{Ba}$ & $27.47 \mathrm{Ba}$ & $19.92 \mathrm{Bb}$ & $25.34 \mathrm{Ba}$ & $22.14 \mathrm{Cb}$ & - & & \\
\hline \multirow{3}{*}{$\mathrm{Cr}$} & $\mathrm{CM}$ & $73.47 \mathrm{Bb}$ & $61.82 \mathrm{Ac}$ & $92.51 \mathrm{Ba}$ & $81.43 \mathrm{Ab}$ & $52.58 \mathrm{Bc}$ & $77.08 \mathrm{Ab}$ & $51.76 \mathrm{Ac}$ & - & \multirow{3}{*}{12.02} & \multirow{3}{*}{150} \\
\hline & NT & $90.54 \mathrm{Ab}$ & $67.81 \mathrm{Ac}$ & $174.71 \mathrm{Aa}$ & $56.72 \mathrm{Bd}$ & $88.59 \mathrm{Ab}$ & $85.75 \mathrm{Ab}$ & $50.37 \mathrm{Ad}$ & - & & \\
\hline & $\mathrm{AC}$ & $40.17 \mathrm{Cb}$ & $26.03 \mathrm{Bb}$ & $33.63 \mathrm{Cb}$ & $73.21 \mathrm{Aa}$ & $36.32 \mathrm{Cb}$ & $61.00 \mathrm{Ba}$ & $37.59 \mathrm{Ab}$ & - & & \\
\hline \multirow{3}{*}{$\mathrm{Cu}$} & $\mathrm{CM}$ & $15.95 \mathrm{Ad}$ & $15.95 \mathrm{Ad}$ & $30.86 \mathrm{Ac}$ & $35.64 \mathrm{Ab}$ & $39.87 \mathrm{Aa}$ & $30.52 \mathrm{Bc}$ & $15.19 \mathrm{Ad}$ & - & \multirow{3}{*}{9.27} & \multirow{3}{*}{200} \\
\hline & NT & $15.24 \mathrm{Ad}$ & $14.97 \mathrm{Ad}$ & $33.23 \mathrm{Ab}$ & $31.64 \mathrm{Ab}$ & $41.22 \mathrm{Aa}$ & $28.43 \mathrm{Bc}$ & $15.28 \mathrm{Ad}$ & - & & \\
\hline & $\mathrm{AC}$ & $14.01 \mathrm{Ac}$ & $13.51 \mathrm{Ac}$ & $28.02 \mathrm{Bb}$ & $34.82 \mathrm{Aa}$ & $33.22 \mathrm{Ba}$ & $34.09 \mathrm{Aa}$ & $14.39 \mathrm{Ac}$ & - & & \\
\hline \multirow{3}{*}{$\mathrm{Zn}$} & $\mathrm{CM}$ & $18.55 \mathrm{Ad}$ & $74.29 \mathrm{Ac}$ & $115.46 \mathrm{Ab}$ & $98.97 \mathrm{Bb}$ & $184.51 \mathrm{Aa}$ & $131.90 \mathrm{Ab}$ & $39.79 \mathrm{Ad}$ & - & \multirow{3}{*}{20.00} & \multirow{3}{*}{450} \\
\hline & NT & $34.95 \mathrm{Ab}$ & $33.97 \mathrm{Bb}$ & $133.00 \mathrm{Aa}$ & $141.84 \mathrm{Aa}$ & $161.33 \mathrm{Aa}$ & $147.00 \mathrm{Aa}$ & $39.23 \mathrm{Ab}$ & - & & \\
\hline & $\mathrm{AC}$ & $36.17 \mathrm{Ad}$ & $44.33 \mathrm{Bd}$ & $82.15 \mathrm{Bc}$ & $153.44 \mathrm{Aa}$ & $149.98 \mathrm{Aa}$ & $115.30 \mathrm{Ab}$ & 36.69Ad & - & & \\
\hline \multirow{4}{*}{ As } & $\mathrm{CM}$ & - & - & - & - & - & - & - & $0.70 \mathrm{~B}$ & \multirow{4}{*}{15.95} & \multirow{4}{*}{35} \\
\hline & NT & - & - & - & - & - & - & - & $0.82 \mathrm{~A}$ & & \\
\hline & $\mathrm{AC}$ & - & - & - & - & - & - & - & $0.45 \mathrm{C}$ & & \\
\hline & Aver & $0.72 \mathrm{a}$ & $0.65 \mathrm{a}$ & $0.70 \mathrm{a}$ & $0.60 \mathrm{~b}$ & $0.56 \mathrm{~b}$ & $0.68 \mathrm{a}$ & $0.67 \mathrm{a}$ & - & & \\
\hline
\end{tabular}

Note. Score: T1-Control; T2-Chemical fertilization; T3-Composted sewage sludge; T4-Vermicompost sewage sludge; T5-Solarized sewage sludge; T6-Sewage sludge dried in dryer; T7-Lime sewage sludge; MC-Maximum contented limit for farming soils in a dry basis; (Minas Gerais, 2011); CM-Cambisol; NT-Nitisol; AC-Acrisol; Aver-Average.

For each variable, means followed by the same upper-case letter in the vertical or lower-case letter in the horizontal are not statistically different from each other by the Scott-Knott test at $5 \%$ of probability.

The contents of $\mathrm{Pb}, \mathrm{Cr}, \mathrm{Cu}$, and $\mathrm{Zn}$ were considered low in the soils of the control treatments, chemical fertilization and fertilization with sewage sludge (Table 4). This fact can be attributed to the lower contribution of these elements in the fertilization process (Table 3). For As, lower contents were obtained in soils fertilized with vermicompost sludge and solarized sludge, indicating that the addition of these composts may have contributed to the addition of fulvic acids, which compete with As for adsorption sites of soil minerals, mainly iron, making it possible to obtain losses by volatilization or absorption by plants at moderately acidic $\mathrm{pH}$ (Grafe et al., 2002), as observed in these soils (pH 5.5 \pm 0.5 , data not shown).

Based on the results achieved in the study, it can be stated that after the application of chemical or sludge fertilizers, the levels of heavy metals in the soil were below the critical limits established by COPAM Normative Resolution No. 166 of Minas Gerais, published on June 29, 2011 (Minas Gerais, 2011), suggesting the safe use of sludge or sludge compounds in agriculture due to the smallest content of heavy metals in these soils. However, there are many discrepancies in the literature regarding levels of soil contamination with heavy metals from the sewage sludge, which vary greatly depending on the soil, the quality of the sewage sludge and its by-products, the applied dose and the frequency of fertilization (Nogueira et al., 2007, 2008; Zuba Junio et al., 2011; Nascimento et al., 2014a, 2014b, 2015).

The absorption of heavy metals by the pineapple tissues was influenced by the soil classes and fertilization types, obtaining the interaction of these factors for $\mathrm{Cu}$ contents, and simple effects for the other elements (Table 5). The highest leaf contents of $\mathrm{Cu}$ were observed in the Argissolo fertilized with composted sludge and in the Nitossolo fertilized with vermicompost. However, these levels of $\mathrm{Cu}$ in the $\mathrm{D}$ leaf were considered below the excessive limits described by Kabata-Pendias and Pendias (2001). 
Table 5. Contents of heavy metal in the D leaf of the pineapple fertilized with chemical fertilizer and types of sewage sludge

\begin{tabular}{|c|c|c|c|c|c|c|c|c|c|c|c|}
\hline \multirow{2}{*}{ Element $\left(\mathrm{mg} \mathrm{kg}^{-1}\right)$} & \multirow{2}{*}{ Soil } & \multicolumn{7}{|c|}{ Treatments } & \multirow{2}{*}{ Aver } & \multirow{2}{*}{$\mathrm{CV}(\%)$} & \multirow{2}{*}{ Exc } \\
\hline & & $\mathrm{T} 1$ & $\mathrm{~T} 2$ & T3 & $\mathrm{T} 4$ & T5 & T6 & $\mathrm{T} 7$ & & & \\
\hline \multirow{4}{*}{$\mathrm{Cu}$} & $\mathrm{CM}$ & $3.10 \mathrm{Aa}$ & $3.60 \mathrm{Aa}$ & $2.94 \mathrm{Ba}$ & $2.52 \mathrm{Ba}$ & $2.77 \mathrm{Aa}$ & 4.39Aa & $4.48 \mathrm{Aa}$ & - & \multirow{4}{*}{54.27} & \multirow{4}{*}{$20-100$} \\
\hline & NT & $2.43 \mathrm{Ab}$ & $4.66 \mathrm{Ab}$ & $3.05 \mathrm{Bb}$ & $10.54 \mathrm{Aa}$ & $2.98 \mathrm{Ab}$ & $3.73 \mathrm{Ab}$ & $3.35 \mathrm{Ab}$ & - & & \\
\hline & $\mathrm{AC}$ & $2.15 \mathrm{Aa}$ & $2.90 \mathrm{Aa}$ & $6.84 \mathrm{Aa}$ & $2.54 \mathrm{Ba}$ & $3.71 \mathrm{Aa}$ & $4.47 \mathrm{Aa}$ & $3.33 \mathrm{Aa}$ & - & & \\
\hline & Aver & - & - & - & - & - & - & - & & & \\
\hline \multirow{3}{*}{$\mathrm{Pb}$} & $\mathrm{CM}$ & - & - & - & - & - & - & - & $0.71 \mathrm{~B}$ & \multirow{3}{*}{72.71} & \multirow{4}{*}{$30-300$} \\
\hline & NT & - & - & - & - & - & - & - & $0.96 \mathrm{~B}$ & & \\
\hline & $\mathrm{AC}$ & - & - & - & - & - & - & - & $1.51 \mathrm{~A}$ & & \\
\hline \multirow{5}{*}{$\mathrm{Cr}$} & Aver & $1.08 \mathrm{a}$ & $0.83 \mathrm{a}$ & $0.92 \mathrm{a}$ & $0.80 \mathrm{a}$ & $1.05 \mathrm{a}$ & $1.03 \mathrm{a}$ & $1.69 \mathrm{a}$ & & & \\
\hline & $\mathrm{CM}$ & - & - & - & - & - & - & - & $1.73 \mathrm{~A}$ & \multirow{4}{*}{29.66} & \multirow{4}{*}{$5-30$} \\
\hline & NT & - & - & - & - & - & - & - & $1.56 \mathrm{~A}$ & & \\
\hline & $\mathrm{AC}$ & - & - & - & - & - & - & - & $1.42 \mathrm{~A}$ & & \\
\hline & Aver & $1.47 \mathrm{a}$ & $1.55 \mathrm{a}$ & $1.61 \mathrm{a}$ & $1.77 \mathrm{a}$ & $1.66 \mathrm{a}$ & $1.59 \mathrm{a}$ & $1.33 \mathrm{a}$ & & & \\
\hline \multirow{4}{*}{$\mathrm{Zn}$} & $\mathrm{CM}$ & - & - & - & - & - & - & - & $14.59 \mathrm{~A}$ & \multirow{4}{*}{48.23} & \multirow{4}{*}{$100-400$} \\
\hline & NT & - & - & - & - & - & - & - & $13.59 \mathrm{~A}$ & & \\
\hline & $\mathrm{AC}$ & - & - & - & - & - & - & - & $10.91 \mathrm{~A}$ & & \\
\hline & Aver & $9.41 \mathrm{~b}$ & $12.05 \mathrm{~b}$ & $17.95 \mathrm{a}$ & $18.89 \mathrm{a}$ & $12.89 \mathrm{~b}$ & $9.10 \mathrm{~b}$ & $10.91 \mathrm{~b}$ & & & \\
\hline \multirow{4}{*}{$\mathrm{Ba}$} & $\mathrm{CM}$ & - & - & - & - & - & - & - & $1.91 \mathrm{~A}$ & \multirow{4}{*}{37.90} & \multirow{4}{*}{500} \\
\hline & NT & - & - & - & - & - & - & - & $1.97 \mathrm{~A}$ & & \\
\hline & $\mathrm{AC}$ & - & - & - & - & - & - & - & $2.18 \mathrm{~A}$ & & \\
\hline & Aver & $2.16 \mathrm{~b}$ & $3.03 \mathrm{a}$ & $1.43 b$ & $1.79 b$ & $1.45 b$ & $1.55 \mathrm{~b}$ & $2.73 a$ & & & \\
\hline \multirow{4}{*}{ As } & $\mathrm{CM}$ & - & - & - & - & - & - & - & $0.08 \mathrm{~A}$ & \multirow{4}{*}{116.44} & \multirow{4}{*}{$5-20$} \\
\hline & NT & - & - & - & - & - & - & - & $0.04 \mathrm{~A}$ & & \\
\hline & $\mathrm{AC}$ & - & - & - & - & - & - & - & $0.04 \mathrm{~A}$ & & \\
\hline & Aver & $0.05 \mathrm{a}$ & $0.08 \mathrm{a}$ & $0.06 \mathrm{a}$ & $0.05 \mathrm{a}$ & $0.04 \mathrm{a}$ & $0.05 \mathrm{a}$ & $0.05 \mathrm{a}$ & & & \\
\hline \multirow{4}{*}{$\mathrm{Se}$} & $\mathrm{CM}$ & - & - & - & - & - & - & - & $0.57 \mathrm{~A}$ & \multirow{4}{*}{393.24} & \multirow{4}{*}{$5-30$} \\
\hline & NT & - & - & - & - & - & - & - & $0.12 \mathrm{~A}$ & & \\
\hline & $\mathrm{AC}$ & - & - & - & - & - & - & - & $0.50 \mathrm{~A}$ & & \\
\hline & Aver & $0.07 \mathrm{a}$ & $0.28 \mathrm{a}$ & $0.10 \mathrm{a}$ & $0.13 \mathrm{a}$ & $0.08 \mathrm{a}$ & $0.10 \mathrm{a}$ & $1.13 \mathrm{a}$ & & & \\
\hline
\end{tabular}

Note. Score: T1-Control; T2-Chemical fertilization; T3-Composted sewage sludge; T4-Vermicompost sewage sludge; T5-Solarized sewage sludge; T6-Sewage sludge dried in dryer; T7-Lime sewage sludge; CM-Cambisol; NT-Nitisol; AC-Acrisol; Exc-excess of the element according to Kabata-Pendias and Pendias (2001); Aver-Average.

For each variable, means followed by the same upper case in the vertical or lower-case letter in the horizontal are not statistically different from each other by the Scott-Knott test at $5 \%$ of probability.

The average content of $\mathrm{Pb}$ in pineapple tissues was greater in the treatment with Acrisol (Table 5), even with the lowest levels in this soil compared to the others (Table 4), showing that other chemical and physical characteristics of Acrisol have interfered in the absorption of $\mathrm{Pb}$ by plants such as the greater presence of organic compounds of low molecular weight responsible for the greater mobility of metals in the soil, the largest native organic matter contents of the soil were achieved in the Acrisol. However, for the elements $\mathrm{Cr}, \mathrm{Zn}, \mathrm{Ba}$, As and Se, no difference was found in the contents in the D leaf among the orders of soils.

The application of composted and vermicompost sludge also increased the $\mathrm{Zn}$ content in the pineapple $\mathrm{D}$ leaf, with no differences among the other types of fertilization (Table 5). Besides the greater application of the compost and vermicompost sludge, it is inferred that these composts contributed to a higher formation of soluble organo-mineral complexes between $\mathrm{Zn}, \mathrm{Cu}$, and humic substances, making these elements less susceptible to soil interactions and more available for absorption by the plants (García-Mina et al., 2004). The $\mathrm{Zn}$ content presented lower values with the addition of dry and solarized sludge, even with greater application of this element by these residues. This may imply that the less stabilized organic matter of these residues may contribute to the decrease in the availability of the $\mathrm{Zn}$ content in the soil and consequently in the various parts of the plants.

The application of chemical fertilization and limed sludge increased the content of $\mathrm{Ba}$ in the leaves in comparison to the other treatments (Table 5). In this case, the increase of $\mathrm{Ba}$ in the leaves is not related to the direct input of fertilizers to the soil (Table 3), but due to the solubilization of native $\mathrm{Ba}$ in the soil, as a consequence of chemical 
and biological reactions caused by the application of fertilizers. As a result, there seems to have been an effect of the organic matter of the sewage sludge in the reduction of the absorption of this element by the plant. Although for some heavy metals there may be increased availability in the presence of organic matter, for elements such as $\mathrm{Ba}$, sulfur bonds and precipitation in the form of barium sulphates or carbonates may occur, reducing their availability and absorption by the plant (Ippolito \& Barbarick, 2006), mainly in the range of pH close to neutrality or alkaline conditions (Abreu et al., 2012). On the other hand, the contents of Cr, As and Se in leaf D were not influenced by the application of the different types of fertilizers.

The heavy metals levels obtained in pineapple tissues were below those considered excessive or that could cause toxicity to the plant (Kabata-Pendias \& Pendias, 2001). In addition, no substantial differences occurred among the contents of heavy metals in the leaf when the fertilization was carried out with sewage sludge or with mineral fertilizer. Similar behavior was observed by Mota et al. (1990), when studying the contents of $\mathrm{As}, \mathrm{Ba}, \mathrm{Pb}, \mathrm{Cu}, \mathrm{Cd}$, $\mathrm{Cr}, \mathrm{Ni}$ and $\mathrm{Zn}$ in leaves of varieties of pineapples fertilized with sewage sludge and mineral fertilizer. According to the authors, Zn was the only element that presented higher levels in the leaves of the pineapples in fertilization with sewage sludge, compared to mineral fertilization.

In the evaluation of the contents of metals present in the pineapple fruit (Table 6), an interaction between the orders of soils and the types of fertilization was observed for $\mathrm{Pb}$ and As. The $\mathrm{Zn}$ content in the fruit was influenced by the types of fertilization and the other elements, $\mathrm{Cr}, \mathrm{Cu}, \mathrm{Ba}$, and $\mathrm{Se}$ were not altered by the treatments.

Table 6. Contents of heavy metals in pineapple fruit fresh mass fertilized with chemical fertilizer and types of sewage sludge

\begin{tabular}{|c|c|c|c|c|c|c|c|c|c|c|c|}
\hline \multirow{2}{*}{ Element $\left(\mathrm{mg} \mathrm{kg}^{-1}\right)$} & \multirow{2}{*}{ Soil } & \multicolumn{7}{|c|}{ Treatments } & \multirow{2}{*}{ Aver } & \multirow{2}{*}{ CV (\%) } & \multirow{2}{*}{ ML } \\
\hline & & T1 & $\mathrm{T} 2$ & $\mathrm{~T} 3$ & $\mathrm{~T} 4$ & T5 & T6 & $\mathrm{T} 7$ & & & \\
\hline \multirow{4}{*}{$\mathrm{Pb}$} & $\mathrm{CM}$ & $0.13 \mathrm{Aa}$ & $0.11 \mathrm{Aa}$ & $0.12 \mathrm{Aa}$ & $0.08 \mathrm{Ba}$ & 0.09Aa & $0.15 \mathrm{Aa}$ & $0.06 \mathrm{Ba}$ & - & \multirow{4}{*}{57.58} & \multirow{4}{*}{$* 0.10$} \\
\hline & NT & $0.08 \mathrm{Aa}$ & $0.07 \mathrm{Aa}$ & $0.09 \mathrm{Aa}$ & $0.07 \mathrm{Ba}$ & $0.06 \mathrm{Aa}$ & $0.10 \mathrm{Aa}$ & $0.15 \mathrm{Aa}$ & - & & \\
\hline & $\mathrm{AC}$ & $0.18 \mathrm{Ab}$ & $0.12 \mathrm{Ab}$ & $0.14 \mathrm{Ab}$ & $0.40 \mathrm{Aa}$ & $0.10 \mathrm{Ab}$ & $0.13 \mathrm{Ab}$ & $0.23 \mathrm{Ab}$ & - & & \\
\hline & Aver & - & - & - & - & - & - & - & & & \\
\hline \multirow{4}{*}{ As } & $\mathrm{CM}$ & $0.003 \mathrm{Aa}$ & $0.003 \mathrm{Aa}$ & $0.002 \mathrm{Ba}$ & $0.003 \mathrm{Ba}$ & $0.012 \mathrm{Aa}$ & $0.002 \mathrm{Aa}$ & $0.002 \mathrm{Aa}$ & - & \multirow{4}{*}{111.76} & \multirow{4}{*}{$* 0.30$} \\
\hline & NT & $0.003 \mathrm{Aa}$ & $0.003 \mathrm{Aa}$ & $0.002 \mathrm{Ba}$ & $0.002 \mathrm{Ba}$ & $0.002 \mathrm{Ba}$ & $0.002 \mathrm{Aa}$ & $0.002 \mathrm{Aa}$ & - & & \\
\hline & $\mathrm{AC}$ & $0.002 \mathrm{Ab}$ & $0.002 \mathrm{Ab}$ & $0.015 \mathrm{Aa}$ & $0.018 \mathrm{Aa}$ & $0.014 \mathrm{Aa}$ & $0.009 \mathrm{Ab}$ & $0.006 \mathrm{Ab}$ & - & & \\
\hline & Aver & - & - & - & - & - & - & - & & & \\
\hline \multirow{4}{*}{$\mathrm{Cr}$} & $\mathrm{CM}$ & - & - & - & - & - & - & - & $0.14 \mathrm{~A}$ & \multirow{4}{*}{36.26} & \multirow{4}{*}{$* * 0.10$} \\
\hline & NT & - & - & - & - & - & - & - & $0.14 \mathrm{~A}$ & & \\
\hline & $\mathrm{AC}$ & - & - & - & - & - & - & - & $0.17 \mathrm{~A}$ & & \\
\hline & Aver & $0.18 \mathrm{a}$ & $0.14 \mathrm{a}$ & $0.16 \mathrm{a}$ & $0.14 \mathrm{a}$ & $0.14 \mathrm{a}$ & $0.15 \mathrm{a}$ & $0.14 \mathrm{a}$ & & & \\
\hline \multirow{4}{*}{$\mathrm{Cu}$} & $\mathrm{CM}$ & - & - & - & - & - & - & - & $0.43 \mathrm{~A}$ & \multirow{4}{*}{56.4} & \multirow{4}{*}{$* * * 10$} \\
\hline & NT & - & - & - & - & - & - & - & $0.42 \mathrm{~A}$ & & \\
\hline & $\mathrm{AC}$ & - & - & - & - & - & - & - & $0.39 \mathrm{~A}$ & & \\
\hline & Aver & $0.52 \mathrm{a}$ & $0.45 \mathrm{a}$ & $0.38 \mathrm{a}$ & $0.35 \mathrm{a}$ & $0.46 \mathrm{a}$ & $0.41 \mathrm{a}$ & $0.32 \mathrm{a}$ & & & \\
\hline \multirow{4}{*}{$\mathrm{Zn}$} & $\mathrm{CM}$ & - & - & - & - & - & - & - & $1.37 \mathrm{~A}$ & \multirow{4}{*}{41.31} & \multirow{4}{*}{$* * 50.0$} \\
\hline & NT & - & - & - & - & - & - & - & $1.24 \mathrm{~A}$ & & \\
\hline & $\mathrm{AC}$ & - & - & - & - & - & - & - & $1.11 \mathrm{~A}$ & & \\
\hline & Aver & $0.50 \mathrm{c}$ & $0.66 \mathrm{c}$ & $1.58 \mathrm{~b}$ & $1.54 \mathrm{~b}$ & $2.39 \mathrm{a}$ & $1.10 \mathrm{c}$ & $0.90 \mathrm{c}$ & & & \\
\hline \multirow{4}{*}{$\mathrm{Ba}$} & $\mathrm{CM}$ & - & - & - & - & - & - & - & $0.26 \mathrm{~A}$ & \multirow{4}{*}{79.49} & \multirow{4}{*}{-} \\
\hline & NT & - & - & - & - & - & - & - & $0.27 \mathrm{~A}$ & & \\
\hline & $\mathrm{AC}$ & - & - & - & - & - & - & - & $0.25 \mathrm{~A}$ & & \\
\hline & Aver & $0.28 \mathrm{a}$ & $0.34 \mathrm{a}$ & $0.40 \mathrm{a}$ & $0.17 \mathrm{a}$ & $0.19 \mathrm{a}$ & $0.21 \mathrm{a}$ & $0.24 \mathrm{a}$ & & & \\
\hline \multirow{4}{*}{$\mathrm{Se}$} & $\mathrm{CM}$ & - & - & - & - & - & - & - & $0.002 \mathrm{~A}$ & \multirow{4}{*}{202.6} & \multirow{4}{*}{$* * 0.30$} \\
\hline & NT & - & - & - & - & - & - & - & $0.002 \mathrm{~A}$ & & \\
\hline & $\mathrm{AC}$ & - & - & - & - & - & - & - & $0.003 \mathrm{~A}$ & & \\
\hline & Aver & $0.002 \mathrm{a}$ & $0.003 a$ & $0.002 \mathrm{a}$ & $0.003 a$ & $0.002 \mathrm{a}$ & $0.003 a$ & $0.002 \mathrm{a}$ & & & \\
\hline
\end{tabular}

Note. Scores: T1-Control; T2-Chemical fertilization; T3-Composted sewage sludge; T4-Vermicompost sewage sludge; T5-Solarized sewage sludge; T6-Sewage sludge dried in dryer; T7-Lime sewage sludge; CM-Cambisol; NT-Nitisol; AC-Acrisol; LM*-Maximum limits of Inorganic contaminants allowed in food, on a fresh basis (Brasil, 2013); ML*-Maximum limits of Inorganic contaminants allowed in food in a fresh basis (Brasil, 1965); ML***-Maximum limits of inorganic contaminants allowed in food in fresh basis (Brasil, 1998); Aver-Average.

For each variable, means followed by the same upper case in the vertical or lower case in the horizontal are not different from each other by the Scott-Knott test at $5 \%$ of probability. 
Acrisol combined with the application of vermicompost and limed sludge provided a greater content of $\mathrm{Pb}$ in the pineapple fruit, and in association with composted, vermicompost and solarized sludge increased As content in the fruit (Table 6). As already mentioned, the higher organic matter content observed in Acrisol (Table 1) may have caused a greater reduction of the redox potential and consequent reduction of iron oxides, and increased availability of the mentioned metals (Asghar \& Kanehiro, 1988). In addition, there may have been influence of increased addition of fulvic acids by some types of sewage sludge on increasing availability and uptake of As by the plant (Grafe et al., 2002).

It is worth mentioning that Acrisol presented lower buffer capacity (greater content of reminiscent $\mathrm{P}$ ) than the other soils, which may contribute to the smaller adsorption capacity of ions to soil clay minerals, making them more available for the plants. The remaining $\mathrm{P}$ is used to indirectly measure soil buffer capacity in relation to $\mathrm{P}$ (Teixeira et al., 2017) and correlates with soil specific surface (Fontana et al., 2013). In studies on the immobilization of $\mathrm{Pb}$ and As in soils, Pierangeli et al. (2001) and Ladeira et al. (2002) state that the greater adsorption of these elements by the soils, among other factors, is associated with a larger specific surface area, as well as to the high levels of aluminum and iron oxides. Another factor that may have contributed to the higher absorption of these metals in the fruit is the higher content of organic matter of soil, implying a higher availability of low molecular weight chelating compounds.

Overall, the levels of $\mathrm{Pb}$ and $\mathrm{As}$ in pineapple fruits in the Acrisol adjust with the observations made for the contents of these elements in the soil and the D leaf, evidencing that the chemical properties of this soil were, in fact, more favorable to the increase of the availability of these elements. Regarding $\mathrm{Pb}$, the greatest content observed in the pineapple fruit with the application of the limed sludge in the Acrisol (Table 6) may also be attributed to the larger amount of fertilizer applied to this soil, with a greater input of this element (Table 3).

The contents of $\mathrm{Pb}$ and $\mathrm{As}$ in the pineapple fruit did not vary in Cambisol either in Nitisol when the different types of fertilization were applied (Table 6). However, in Acrisol, the fertilization with vermicompost sewage sludge, in the case of $\mathrm{Pb}$, and fertilization with composted, vermicompost and solarized sewage sludge, in the case of the As promoted the highest levels of these elements. Moreover, in relation to $\mathrm{Zn}$, regardless of the soil type, the fertilization with composted, vermicompost and solarized sewage sludge also provided the greatest levels of this element in the fruit, particularly fertilization with solarized sludge. In general, this fact can be attributed to the greater contribution of these elements in the application of sludge-containing fertilizers, except for the sludge dried in a dryer, since because at the high drying temperature, carbonization process occurs, making sewage sludge more recalcitrant to the decomposition and release of the elements.

In the case of $\mathrm{Pb}$ and $\mathrm{Cr}$, the contents of the pineapple fruit were close to or exceeded the maximum limits allowed for food in Brazil (Brasil, 2013) (Table 6). The maximum limits of tolerable heavy metals in Brazil were established by Decree-Law 55871-65 of March 26, 1965 (Brasil, 1965), and maintained and updated by Ministry of Health Ordinance No. 685-980 of 27 of August 27, 1998 (Brasil, 1998) and by the Resolution of the Anvisa-Mercosul Collegiate Board No. 42 of August 29, 2013 (Brasil, 2013).

However, it is noteworthy that the above-mentioned standards refer to fruits in general, without specifying them, and it is important to carry out a more specific estimate for pineapple. Thus, considering the highest levels of $\mathrm{Pb}$, $\mathrm{Cr}$ and $\mathrm{Ba}$ observed in the fresh fruit of the pineapple, which were $0.40 ; 0.18$ and $0.40 \mathrm{mg} \mathrm{kg}^{-1}$, respectively (Table 6), and the daily intake of two slices of pineapple with a total fresh mass estimated at $180 \mathrm{~g}$ for a person with $60 \mathrm{~kg}$ body weight, the intake rates of mentioned heavy metals, in $\mu \mathrm{g} \mathrm{day}{ }^{-1}$, would be $72.0 \mathrm{for} \mathrm{Pb}, 32.4$ for $\mathrm{Cr}$ and 72.0 for $\mathrm{Ba}$. Since the provisional limits of daily intake rates established by international legislation for $\mathrm{Pb}, \mathrm{Cr}$ and $\mathrm{Ba}$ are 210; 1,500; and 1,200 $\mu \mathrm{g} \mathrm{day}^{-1}$, respectively (WHO, 2001; JECFA, 2003; USEPA, 2003), it can be said that the values found in the study were within the safety limits for the consumption of this food.

\section{Conclusions}

Cambisol and Nitisol provide less favorable conditions to the rise in the availability and absorption of $\mathrm{Pb}$ e As by the pineapple fruit.

Fertilization with sewage sludge dried in a dryer and lime sewage sludge provide the lowest concentrations of $\mathrm{Pb}$, As and $\mathrm{Zn}$ in the pineapple fruit, the most suitable types being for fertilization with this residue.

\section{References}

Abreu, C. A., Cantoni, M., Coscione, A. R., \& Paz-Ferreiro, J. (2012). Organic matter and barium absorption by plant species grown in an area polluted with scrap metal residue. Applied and Environmental Soil Science, 1-7. https://doi.org/10.1155/2012/476821

Alcarde, J. C. (2009). Manual de Análise de Fertilizantes (p. 259). Piracicaba, FEALQ. 
Asghar, M., \& Kanehiro, Y. (1988). Effects of sugarcane trash and pineapple residue on tritation curves, redox potential and extractable $\mathrm{Mn}$ e Fe in na oxisol. Biological Wastes, 24, 27-38. https://doi.org/10.1016/ 0269-7483(88)90024-9

Brasil. (1962). Decreto $n^{\circ} 55871$, de 26 de março de 1965. Modifica o Decreto $n^{\circ} 50.040$, de 24 de janeiro de 1961, referente a normas reguladoras do emprego de aditivos para alimentos, alterado pelo Decreto $\mathrm{n}^{\circ} 691$, de 13 de março de 1962.

Brasil. (1998). Ministério da Saúde. Secretaria de Vigilância Sanitária. Portaria nº 685, de 27 de agosto de 1998. Aprova o Regulamento Técnico: "Princípios gerais para o estabelecimento de níveis máximos de contaminantes químicos em alimentos” e seu Anexo: "Limites máximos de tolerância para contaminantes inorgânicos".

Brasil. (2006). Ministério do Meio Ambiente. Conselho Nacional de Meio Ambiente. Resolução n. 375 , de 29 de agosto de 2006. Define critérios e procedimentos, para o uso agrícola de lodos de esgoto gerados em estações de tratamento de esgoto sanitário e seus produtos derivados. Brasília, 2006.

Brasil. (2013). Ministério da Saúde. Agência Nacional de Vigilância Sanitária-Anvisa. Resolução da Diretoria Colegiada-RDC, $n^{\circ} 42$, de 29 de agosto de 2013. Dispõe sobre o Regulamento Técnico MERCOSUL sobre Limites Máximos de Contaminantes Inorgânicos em Alimentos.

Caetano, L. C. S., Ventura, J. A., Costa, A. de F. S. da, \& Guarçoni, R. C. (2013). Efeito da adubação com nitrogênio, fósforo e potássio no desenvolvimento, na produção e na qualidade de frutos do abacaxi 'vitória'. Revista Brasileira de Fruticultura, 35(3) 883-890. https://doi.org/10.1590/S0100-29452013000300027

Cardoso, M. M., Pegoraro, R. F., Maia, V. M., Kondo, M. K., \& Fernandes, L. A. (2013). Crescimento do abacaxizeiro 'vitória' irrigado sob diferentes densidades populacionais, fontes e doses de nitrogênio. Revista Brasileira de Fruticultura, 35(3) 769-781. https://doi.org/10.1590/S0100-29452013000300014

Catunda, M. G., Freitas, S. P., Silva, C. M. M., Carvalho, A. J. R. C., \& Soares, L. M. S. (2006). Interferência de plantas daninhas no acúmulo de nutrientes e no crescimento de plantas de abacaxi. Planta Daninha, 24(1), 199-204. https://dx.doi.org/10.1590/S0100-83582006000100025

Cunha, G. A. P., Cabral, J. R. S., \& Souza, L. F. S. (1999). O abacaxizeiro, cultivo, agroindústria e economia (p. 480). Brasília, Embrapa.

EMBRAPA (Empresa Brasileira de Pesquisa Agropecuária). (1997). Manual de métodos de análise de solo (2nd ed., p. 212). Rio de Janeiro: Embrapa CNPS.

EMBRAPA (Empresa Brasileira de Pesquisa Agropecuária). (2018). Sistema brasileiro de classificação de solos (5th ed.). Rio de Janeiro: Embrapa Solos.

Fontana, A., Pereira, M. G., Santos, A. C. dos, Bernini, T. A., Anjos, L. H. C. dos, Fernandez, C. F. D., \& Peinado, F. J. M. (2013). Fósforo remanescente em solos formados sob diferentes materiais de origem em três topossequências, Pinheiral-RJ. Semina: Ciências Agrárias, 34(5) 2089-2102. https://doi.org/10.5433/ 1679-0359.2013v34n5p2089

García-Mina, J. M., Antolín, M. C., \& Sanchez-Diaz, M. (2004). Metal-humic complexes and plant micronutrient uptake: A study based on different plant species cultivated in diverse soil types. Plant and Soil, 258(1), 57-68. https://doi.org/10.1023/B:PLSO.0000016509.56780.40

Gomes, S. B. V., Nascimento, C. W. A., Biondi, C. M., \& Accioly, A. M. de A. (2006). Distribuição de metais pesados em plantas de milho cultivadas em Argissolo tratado com lodo de esgoto. Revista Ciência Rural, 36(6), 1689-1695. https://doi.org/10.1590/S0103-84782006000600004

Grafe, M., Eick, M. J., Grossl, P. R., \& Saunders, A. M. (2002). Adsorption of arsenate and arsenite on ferrihydrite in the presence and absence of dissolved organic carbon. Journal of Environmental Quality, 31(4), 1115-1123. https://doi.org/10.2134/jeq2002.1115

Ippolito, J. A., \& Barbarick, K. A. (2006). Biosolids affect soil barium in a dryland wheat agroecosystem. Journal of Environmental Quality, 35, 2333-2341. https://doi.org/10.2134/jeq2006.0076

JECFA. (2003). Summary and conclusions of the 61st meeting of the Joint FAO/WHO. Expert Committee on Food Additives (JECFA), JECFA/61/SC. Rome, Italy.

Kabata-Pendias, A. (2001). Trace elements in Soils and Plants (3rd ed., p. 432). CRC Press. https://doi.org/ $10.1201 / 9781420039900$ 
Ladeira, A. C. Q., Ciminelli, V. S. T., \& Nepomuceno, A. L. (2002). Seleção de solos para a imobilização de arsênio. Revista Escola de Minas, 55(3), 215-221. https://doi.org/10.1590/S0370-44672002000300009

Lemainski, J., \& Silva, J. E. (2006). Avaliação agronômica e econômica da aplicação de biossólido na produção de soja. Pesquisa Agropecuária Brasileira, 41(10), 1477-1484. https://doi.org/10.1590/S0100-204X 2006001000004

Malavolta, E. (2006). Manual de nutrição mineral de plantas (p. 638). São Paulo, Editora Ceres.

Mcgrath, S. P., \& Cunliffe, C. H. (1985). A simplified method for the extraction of the metals Fe, Zn, Cu, Ni, Cd, $\mathrm{Pb}, \mathrm{Cr}, \mathrm{Co}$, and $\mathrm{Mn}$ from soils and sewage sludges. Journal of the Science of Food and Agriculture, 36, 794-798. https://doi.org/10.1002/jsfa.2740360906

Minas, G. (2011). Secretaria de Estado de Meio Ambiente e Desenvolvimento Sustentável. Conselho Estadual de Política Ambiental. Fundação Estadual do Meio Ambiente. Deliberação Normativa COPAM $n^{\circ} 166$, de 29 de junho de 2011. Altera o Anexo I da Deliberação Normativa Conjunta COPAM CERH n 2 de 6 de setembro de 2010, estabelecendo os Valores de Referência de Qualidade dos Solos. Belo Horizonte-MG.

Mota, M. F. C., Pegoraro, R. F., Silvânio R. Dos S., Maia, V. M., Sampaio, R. A., \& Kondo, M. K. (2018). Contamination of soil and pineapple fruits under fertilization with sewage sludge. Revista Brasileira de Engenharia Agrícola e Ambiental, 22(5), 320-325. https://doi.org/10.1590/1807-1929/agriambi.v22 n5p320-325

Nascimento, A. L., Sampaio, R. S., Cruz, S. F. da, Zuba Junio, G. R., Barbosa, C. F., \& Fernandes, L. A. (2014a). Metais pesados em girassol adubado com lodo de esgoto submetido a diferentes processos de estabilização. Revista Brasileira de Engenharia Agrícola e Ambiental, 18(7), 694-699. https://doi.org/10.1590/ S1415-43662014000700004

Nascimento, A. L., Sampaio, R. S., Zuba Junio, G. R., Carneiro, J. P., Fernandes, L. A., \& Rodrigues, M. N. (2014b). Teores de metais pesados no solo e em girassol adubado com lodo de esgoto. Revista Brasileira de Engenharia Agrícola e Ambiental, 18(3), 294-300. https://doi.org/10.1590/S1415-43662014000300008

Nascimento, A. L., Zuba Junio, G. R., Sampaio, R. A., Fernandes, L. A., Carneiro, J. C., \& Barbosa, C. F. (2015). Metais pesados no solo e mamoneira adubada com biossólido e silicato de cálcio e magnésio. Revista Brasileira de Engenharia Agrícola e Ambiental, 19(5) 505-511. https://doi.org/10.1590/1807-1929/ agriambi.v19n5p505-511

Nascimento, C. W. A., Barros, D. A. S., Melo, E. E. C., \& Oliveira, A. B. (2004). Alterações químicas em solos e crescimento de milho e feijoeiro após aplicação de lodo de esgoto. Revista Brasileira de Ciência de Solo, 28(2), 385-392. https://doi.org/10.1590/S0100-06832004000200017

Nogueira, T. A. R., Oliveira, L. R., Melo, W. J., Fonseca, I. M., Melo, G. M. P. de, Melo, V. P. de, \& Marques, M. O. (2008). Cádmio, cromo, chumbo e zinco em plantas de milho e em Latossolo após nove aplicações anuais de lodo de esgoto. Revista Brasileira de Ciência de Solo, 32, 2195-2207. https://doi.org/ 10.1590/S0100-06832008000500040

Nogueira, T. A. R., Sampaio, R. A., Fonseca, I. M., Ferreira, C. S., Santos, S. E., Ferreira, L. C., ... Fernandes, L. A. (2007). Metais pesados e patógenos em milho e feijão caupi consorciados, adubados com lodo de esgoto. Revista Brasileira de Engenharia Agrícola e Ambiental, 11(3) 331-338. https://doi.org/10.1590/ S1415-43662007000300014

Oliveira, E. F., Carvalho, R. A., Lacerda, J. T., Choairy, S. A., \& Barreiro Neto, M. (2002). Abacaxi: Sistema de cultivo para o tabuleiro paraibano (p. 38). João Pessoa: EMEPA.

Oliveira, J. P. B. de, Lopes, J. C., Alexandre, R. S., Jasper, A. P. dos S., Santos, L. N. da S., \& Oliveira, L. B. de. (2009). Concentração de metais pesados em plantas de maracujá doce cultivadas em dois solos tratados com lodo de esgoto. Engenharia Ambiental-Espírito Santo do Pinhal, 6(2) 217-223.

Ribeirinho, V. S., Melo, W. J., Silva, D. H., Figueiredo, L. A., \& Melo, G. M. P. (2012). Fertilidade do solo, estado nutricional e produtividade de girassol, em função da aplicação de lodo de esgoto. Pesquisa Agropecuária Tropical, 42(2), 166-173. https://doi.org/10.1590/S1983-40632012000200002

Silva, C. A., Rangel, O. J. P., Dynia, J. F., Bettiol, W., \& Manzatto, C. V. (2006). Disponibilidade de metais pesados para milho cultivado em Latossolo sucessivamente tratado com lodos de esgoto. Revista Brasileira de Ciência de Solo, 30(2), 353-364. https://doi.org/10.1590/S0100-06832006000200015 
Silva, F. C. da (1999). Manual de análises químicas de solos plantas e fertilizantes. Rio de Janeiro, Embrapa Solos/Embrapa Informática Agropecuária.

Souza, M. de, Guimarães, P. T. G., Carvalho, J. G. de, \& Fragoas, J. C. (1999). Sugestões de adubação para plantas frutíferas: Abacaxizeiro. In A. C. Ribeiro, P. T. G. Guimarães, \& V. V. H. Alvarez (Eds.). Recomendações para o uso de corretivos e fertilizantes em Minas Gerais (pp. 209-216). Viçosa: UFV, Comissão de Fertilidade do Solo do Estado de Minas Gerais.

Tedesco, M. J., Gianello, C., Bissani, C. A., Bohnen, H., \& Volkweiss, S. J. (1995). Análise de solo, plantas e outros materiais (2nd ed., p. 174). Porto Alegre, Departamento de Solos da Universidade Federal do Rio Grande do Sul.

Teixeira, P. C., Donagemma, G. K., Fontana, A., \& Teixeira, W. G. (2017). Manual de métodos de análise de solo (p. 573). Brasília: Embrapa.

Tontti, T., Poutiainen, H., \& Heinonen-Tanski, H. (2017). Efficiently treated sewage sludge supplemented with nitrogen and potassium is a good fertilizer for cereals. Land Degradation \& Development, 28, 742-751. https://doi.org/10.1002/ldr.2528

USEPA (United States Environmental Protection Agency). (1999). Final rules standards for the use for disposal of sewage sludge (Title 40 CFR, Part 503). USEPA.

USEPA (United States Environmental Protection Agency). (2018). Integrated Risk Information System Database.

WHO (World Health Organization). (2001). Compounds International Programme on Chemical Safety (Consise International Chemical Assessment Document 33). Geneva.

Zuba Junio, G. R., Sampaio, R. A., Santos, G. B., Nascimento, A. L., Carneiro, J. P., Santos, L. D. T., \& Fernandes, L. A. (2012). Produção de milho adubado residualmente com composto de lodo de esgoto e fosfato de Gafsa. Revista Brasileira de Engenharia Agrícola e Ambiental, 16(12) 1289-1297. https://doi.org/10.1590/S1415-43662012001200005

Zuba Junio, G. R., Sampaio, R. A., Santos, G. B., Nascimento, A. L., Prates, F. B. S., \& Fernandes, L. A. (2011). Metais pesados em milho fertilizado com fosfato natural e composto de lodo de esgoto. Revista Brasileira de Engenharia Agrícola e Ambiental, 15(10), 1082-1088. https://doi.org/10.1590/S1415-43662011001 000013

\section{Copyrights}

Copyright for this article is retained by the author(s), with first publication rights granted to the journal.

This is an open-access article distributed under the terms and conditions of the Creative Commons Attribution license (http://creativecommons.org/licenses/by/4.0/). 